\title{
Protein Pattern of Phoenix dactylifera Seeded Strains Grown in Basrah Region Using Cluster and Principal Component Analysis
}

\author{
Ali H. M. Attaha ${ }^{1}$, Taha Y. Mhoder ${ }^{1} \&$ Abdul-Kareem M. Abd ${ }^{1}$ \\ ${ }^{1}$ Horticulture and Landscape Department, Agriculture College, Basrah University, Basrah, Iraq \\ Correspondence: Ali H. M. Attaha, Horticulture and Landscape Department, Agriculture College, Basrah \\ University, Basrah, Iraq. Tel: 964-0780-241-8069. E-mail: attaha1955@yahoo.com
}

Received: January 28, 2013 Accepted: May 17, 2013 Online Published: July 31, 2013

doi:10.5539/jps.v2n2p149 URL: http://dx.doi.org/10.5539/jps.v2n2p149

\begin{abstract}
The present study was carried out on 17 seeded strains of date palm "Phoenix dactylifera L." grown in Basrah region to investigate variations in protein pattern of leaflets and fruits among these strains. Cluster and principal component analysis were used to identify the degree of similarity and differences between date palm strains. The leaflet and fruit protein pattern on SDS-PAGE showed differences in band number, location, thickness and density leading to variations in protein quantity and quality among the studied strains.Cluster analysis data showed a high degree of similarity between leaflet and fruit samples of these strains recording an average similarity value of 0.76 and 0.67 for leaflet and fruit samples respectively. Cluster analysis also revealed that all strains occupied two main groups and then distributed into two subgroups under each main group. The principal component analysis showed that protein banding characters for leaflets and fruits could be used for identification of date palm seeded strains.
\end{abstract}

Keywords: Phoenix dactylifera, protein pattern, SDS-PAGE, leaflet, fruit

\section{Introduction}

Date palm (Phoenix dactylifera $\mathrm{L} ., 2 \mathrm{n}=2 \mathrm{x}=36$ ), the dioecious, perennial, monocotyledonous fruit tree that belongs to the family Arecaceae, is one of the oldest cultured trees in the world (Barrow, 1998). Date is the dominant fruit crop in southern Iraq and considered to be an important food resource for the population living in this region due to its nutritional and economic values (Al-Bakr, 1972; El-Sohaimy \& Hafez, 2010). Most of the indigenous cultivars of date palm grown in southern Iraq are believed to have originated from seeded strains over a period of 5000 years (Mater, 1991). Strains are selected according to the superiority of vegetative and reproductive characters with successful propagation by offshoots and adaptation to environmental conditions of the region.

Basrah Governorate, the land of dates, has the largest date palm plantation in Iraq with an approximate area of 50 000 hectare covered with 13 million date palm trees and 400 cultivars (Jaradat, 2003). Basrah is situated in the far south of Iraq at the northwestern corner of the Arabian Gulf ( $46^{\circ} 60^{\prime}$ to $48^{\circ} 60^{\prime} \mathrm{E}$ and $29^{\circ} 13^{\prime}$ to $31^{\circ} 29^{\prime} \mathrm{N}$ ), occupying a total area of $19070 \mathrm{~km}^{2}$, elevated 90-260 m above sea level ( Hadeel et al., 2010).

The climate of Basrah is a desert - type environment, characterized by a long, hot and dry summer, and a relatively mild winter, with scanty rainfall $(31.901 \mathrm{~mm}$ in 2010 and $65.3 \mathrm{~mm}$ in 2011-Directorate General of Civil Aviation Meterological Department, Basrah Airport), producing fruits of the best quality in the world (Attaha \& Taain, 2011). However, the number and productivity of date palm trees have reduced severely over the last three decades in Basrah region due to war, urbanization, and over utilization of natural resources (MA, 2004). Therefore, the restoration of date palm orchards was conducted by individual farmers using seed propagation techniques to grow new date palm plantations on a mass scale. This was due to the limitation of an adequate number of offshoots of good cultivars (Attaha, 2007). As a result, random selection of newly risen seeded strains was achieved by farmers using morphological markers like fruit characteristics. Identification of 15 date palm cultivars by fruit fresh weight and size, dry matter percentage, sugars and titratable acidity content as physical and chemical markers was carried out by Elshibli and Korpelainen (2009). Furthermore, biochemical data based on fruit, leaf and seed protein pattern, obtained by electrophoresis, have been used as molecular markers to evaluate genetic differences between date palm cultivars (Sahi \& Al-Anber, 2005; Al-Qurainy et al., 2006; Gomez-Vidal et al., 2008; Abdulla \& Gamal, 2010; Khoshroo et al., 2011). Al-Esa (2006) found changes in the 
electrophoretic patterns of protein bands of leaflets, roots, fruits and seeds of three date palm cultivars grown in two different locations indicating existence of protein qualitative variations between and among cultivars, stages of development and location. The study of electrophoretic protein pattern in leaflets of the tissue-culture date palm and their offshoots origin of four cultivars showed differences in the type and number of their protein bands as well as band thickness and intensity (Al-Qurainy et al., 2006). Therefore, the present study was conducted to evaluate genetic variations by means of protein analysis of date palm-seeded strains using the SDS-Polyacrylamide Gel Electrophoresis technique.

\section{Materials and Methods}

Seventeen female seeded strains of date palm grown under field conditions in a private orchard at Abu ElKhasseb District, Basrah Governorate, were selected for this study. Selected date palm trees were 10 to 12-years old, with equal size and vigour, and subjected to the common cultural practices. Pollination was performed using pollen grains from male local cultivar "Ghanami Akhder" at the commencement of flowering in April, 2010.

Samples were, collected from current season mature leaves in June, 2010 and from fruits at Khalal stage in July, 2010. Collected samples were cleaned and rinsed thoroughly in tap water to remove dust and then left to dry at room temperature for 2 hours. Protein analysis was carried out at the Molecular Genetics Laboratory at the College of Agriculture, University of Basrah.

Samples of leaflets and fruits were freeze dried at $-26^{\circ} \mathrm{C}$ for 48 hours using a Freeze-Dryer Apparatus (Edwords, Pirani 501, Germany). Two grams of each sample were ground in $14 \mathrm{ml}$ cold concentrated acetone, three times, and then mixed by vortex for one minute in the extraction buffer of $\mathrm{pH} 7.0\left(0.2 \mathrm{M} \mathrm{NaH}_{2} \mathrm{PO}_{4}, 5 \% \mathrm{SDS}, 4 \mathrm{M}\right.$ urea $)$ following the procedure of Shaheen \& El- Meleigi (1991). The mixtures were then centrifuged at $4000 \mathrm{rpm}$ for 15 minutes. The supernatants were collected and proteins were precipitated by adding cold acetone $(1: 4, \mathrm{v} / \mathrm{v})$. Precipitated proteins were recovered by centrifugation at $10000 \mathrm{rpm}$ for 15 minutes.

Precipitated proteins were dissolved in a sample buffer containing $0.5 \mathrm{M}$ Tris- $\mathrm{HCl} \mathrm{pH} 6.8,10 \%$ SDS, $0.5 \% 2$ -mercaptoethanol, $0.5 \%$ bromophenol blue, $20 \%$ sucrose. The protein extract was heated at $90^{\circ} \mathrm{C}$ for 5 minutes to facilitate protein denaturation and left to cool at room temperature before electrophoresis. Proteins were separated by SDS-PAGE technique according to Laemmli (1970) as described by Carffin (1990). Electrophoresis was carried out by the Vertical Slab Gel Apparatus (Cleaver Scientific, UK).

$50 \mu \mathrm{l}$ of protein samples were resolved on a running gel containing $7.5 \mathrm{ml}$ of $7.5 \%$ acrylamide, $7.5 \mathrm{ml}$ of $1.5 \mathrm{M}$ Tris- $\mathrm{HCl} \mathrm{pH} 8.8,0.3 \mathrm{ml}$ of $10 \%$ SDS, $150 \mu \mathrm{l}$ of $1.5 \%$ ammonium persulfate, $15 \mu \mathrm{l}$ TEMED, $14.7 \mathrm{ml}$ distilled water, followed by a stacking gel containing $2.6 \mathrm{ml}$ of $7.5 \%$ acrylamide, $5 \mathrm{ml}$ of $0.5 \mathrm{M}$ Tris- $\mathrm{HCl} \mathrm{pH} 6.8,0.2 \mathrm{ml}$ of $10 \% \mathrm{SDS}, 50 \mu \mathrm{l}$ of $1.5 \%$ ammonium persulfate, $10 \mu \mathrm{TEMED}, 12.2 \mathrm{ml}$ distilled water.

The running buffer contained a mixture of $1.5 \mathrm{gm}$ Tris- $\mathrm{HCl} \mathrm{pH} 8.3,7.2 \mathrm{gm}$ glycine, $5 \mathrm{ml}$ of $10 \%$ SDS. Gels were run at a low temperature $\left(12{ }^{\circ} \mathrm{C}\right)$ for 3 to 4 hours at a constant voltage of $50 \mathrm{~mA}$ until the tracking dye (bromophenol blue ) reaches the end of the gel. Gels were stained, as described by Howland (1996), with $0.1 \%$ Coomassie brilliant blue R250 for 24 hours and then de-stained, to remove the unbound dye, with a solution containing a mixture of acetic acid and methanol and distilled water in a ratio of 1:4:5, respectively, untill the background became transparent.

Gel was photographed under UV light with Gel Documentation System and data was analysed using UV-band software program supplied by Cambridge University (2010). A dendrogram was generated by cluster analysis using the Unweighted Pair Group Method of the Arithmetic Averages "UPGMA". Principal Component Analysis "PCA" was carried out by computing the protein data with SPSS programs, version 16, software.

\section{Results and Discussion}

The results of SDS-PAGE analysis of proteins extracted from leaves of the 17 date palm seeded strains showed a noticeable difference in banding pattern of the protein of these strains with the number and location of bands being varied among the studied strains (Plate 1). Al-Qurainy et al. (2006) also found differences in the type and bands number of leaflet proteins separated by SDS- PAGE gel among four date palm cultivars of offshoot origin and their comparable tissue- culture trees. Cluster analysis data obtained from these strains exhibited two main groups (Figure 1). The first group consisted of three strains: 2, 3 and 4, whereas the second group included fourteen strains in two subgroups. The first subgroup was made of three strains: 5, 13 and 15, and the remaining eleven strains constituted the second subgroup with strain 1 being distinctive in comparison to the other strains in the second group. Figure (1) also revealed that the most related among the 17 female strains were strains 14 and 19 recording the highest similarity value of 0.999 . The strain 24 was closely related to both strains 14 and 19 with the second highest similarity value of 0.998 . Strains 26 and 27 showed the same similarity value of 0.984 
than strains 28 and 29. The average similarity value among the seeded strains was 0.76 . Figures 2 and 3 showed the distribution of the seeded strains according to the principal component analysis. The results of components 1 and 2 (Figure 2) revealed that there were significant differences between the strains 29 and 3 and 26 and 4 . On the other hand, strains 3 and 4 and 26 and 27 and 28 and 29 were closely placed in the diagram. Regarding to the results of components 1 and 3, it would be noticed (Figure 3) that date palm strains were distributed randomly in the diagram. Significant differences were found between strains 5 and 1 and 5 and 4, but strains 3 and 4 and 28 and 29 were closely positioned in the diagram. Results suggest that these strains have the same genetic origin. But, during seedling development they diverged into different strains that have specific characters to be separated from each other. The variations in the protein patterns of leaves of the 17 date palm seeded strains obtained from the cluster analysis and principal component analysis could be due to the gene expression products of each strain indicating that these strains had a narrow genetic base in accordance with the average similarity degree of 0.76 between these strains (Figure 1). It appears that they are different strains from similar origin.
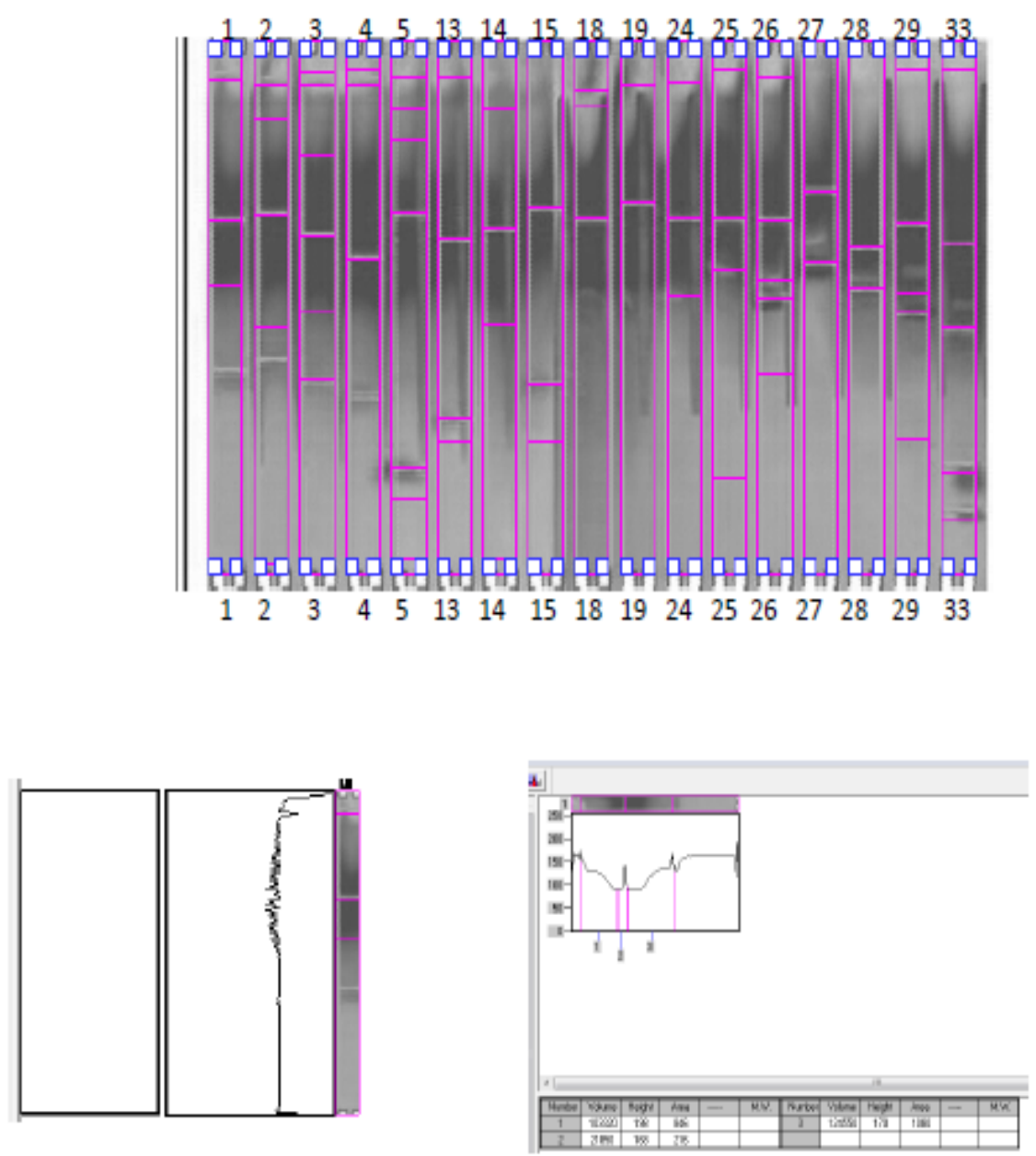

Plate 1. Scanning of SDS-PAGE gel of leaf protein of date palm seeded strains 


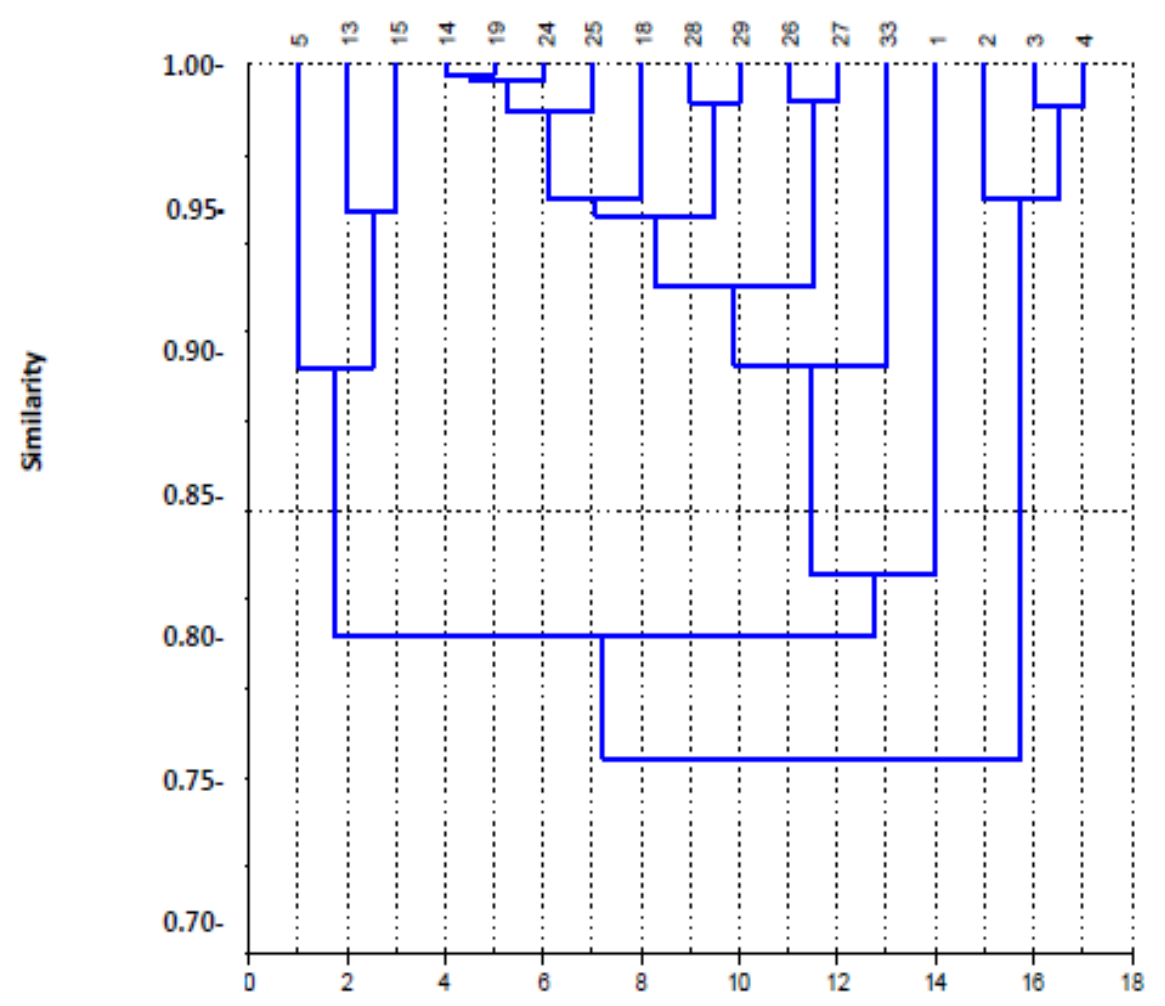

Figure 1. Genetic relationships of date palm seeded strains obtained using electrophoresis pattern of leaf protein

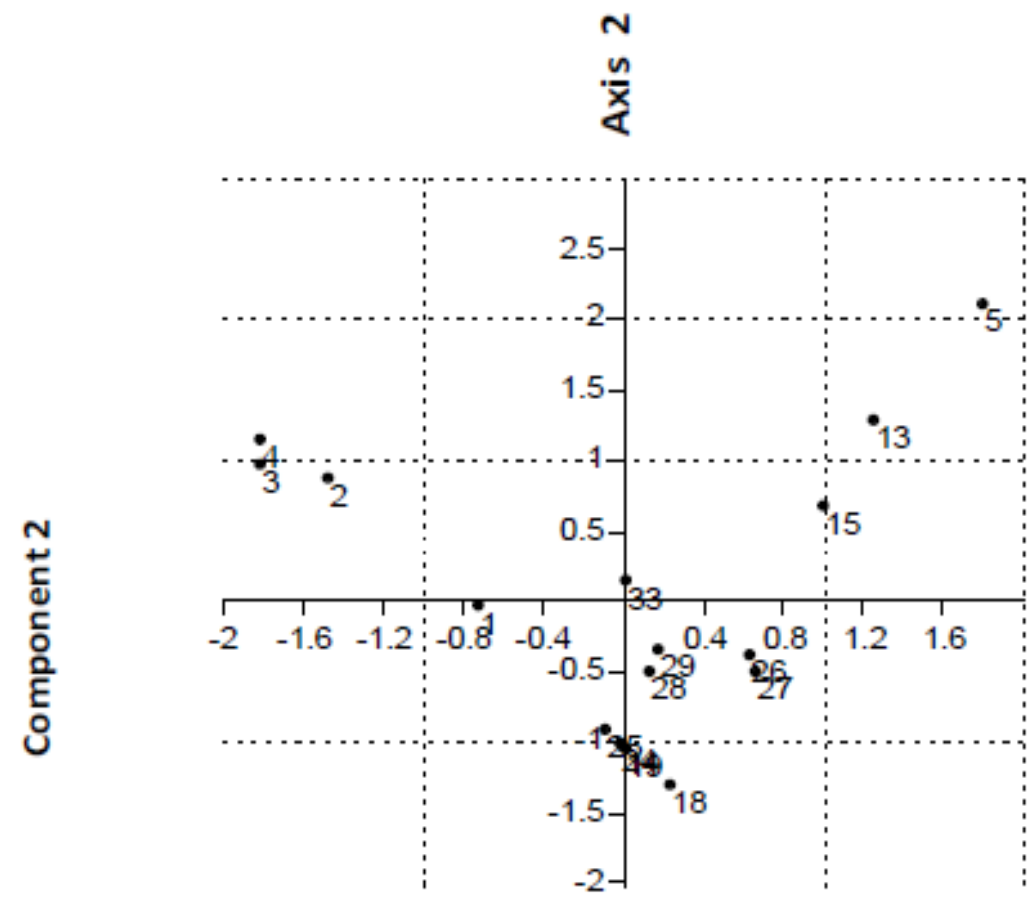

Axis1

\section{Component 1}

Figure 2. First and second principal components (PC 1 and PC 2 ) from PCA of date palm seeded strains based on leaves protein bands data 


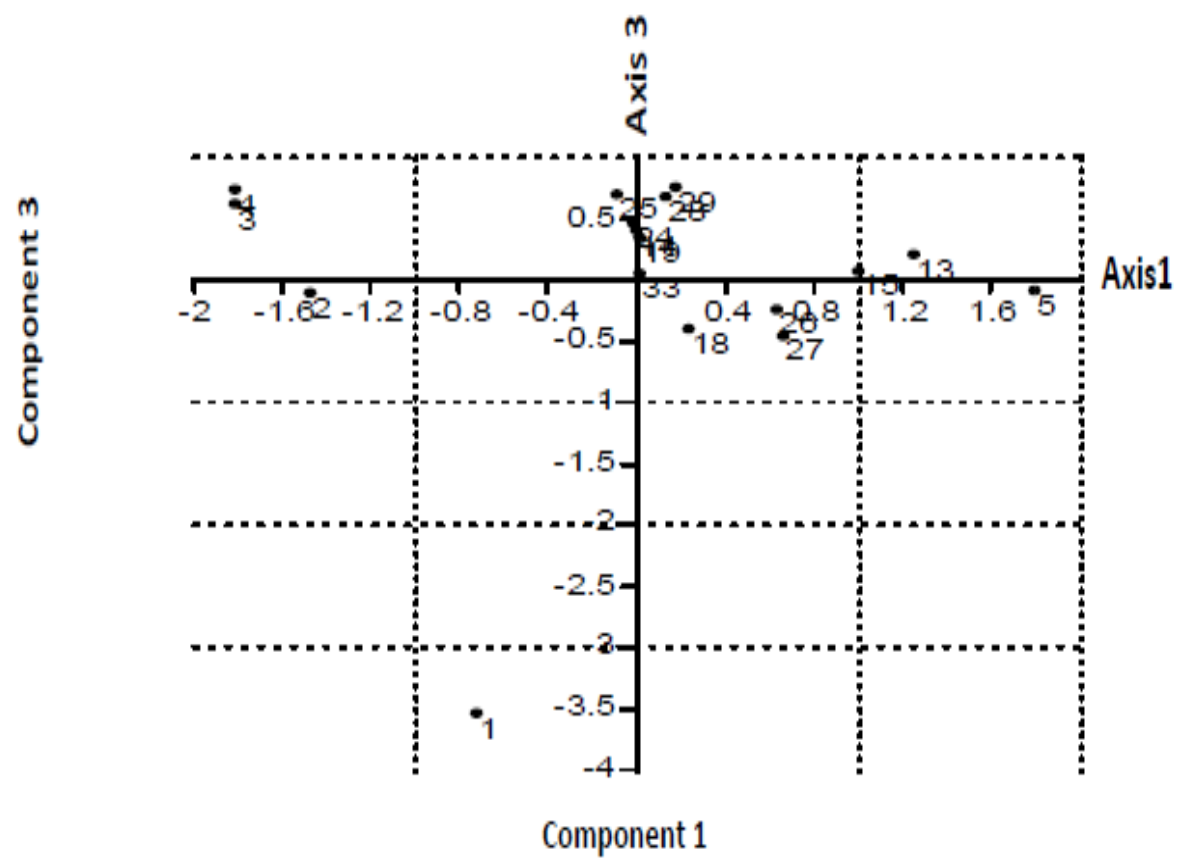

Figure 3. First and third principal components (PC 1 and PC 3) from PCA of date palm seeded strains based on leaves protein bands data

The SDS- electrophoresis patterns of proteins extracted from fruits of the 17 date palm seeded strains are illustrated in Plate (2). Differences were observed in the number, location and banding characters of the protein patterns of the 17 strains. Cluster analysis data of protein banding pattern of the studied strains displayed two main groups (Figure 4). Group 1 included the strains 3, 5, 25, 13, 14, 18, 24 and 27 whereas group 2 consisted of the remaining strains. Strains of group 1 exhibited two subgroups with strain 27 consisting of subgroup 1 and the other strains $(3,5,25,13,14,18$, and 24) were listed in subgroup 2. Strains of group 2 were also placed in two subgroups in which the strains 4, 28 and 29 were made up of the first subgroup and strains 15, 19, 33, 1, 26 and 2 occupied the second subgroup. As shown in Figure (4), the most closely lumped strains were 18 and 24 recording the highest similarity value of 0.98 , and the strains 28 and 29 displayed the second highest similarity value of 0.97 . The average similarity value among the 17 strains was found to be 0.67 . The distribution of these strains on component 1 and 2 (Figure 5) revealed significant differences occurring between strains 6 and 4, 28 and 29, but strains 18, 24 and 27 and 4, 28 and 29 were closely distanced from each other in the diagram. Regarding to these results, differences or similarities appear to axist between these strains, but they remain strains carrying their own genetic contents. On the other hand, the distribution of these strains according to components 1 and 3 appeared to be randomly aggregated in the diagram (Figure 6). Significant differences occurred between strains 27 and 2, but strains 18 and 24 and 5 and 25 were closely positioned in the diagram. The variations in fruit protein patterns based on cluster analysis and principal component analysis showed a narrow genetic base between the studied strains which was most likely related to the phenomenon of "metaxinia" as pollen grains of Ghanami Akhder male had a direct effect on fruit protein synthesis influencing protein bands characters of the strains. These results were in agreement with those obtained by Abdel-Hamid (2000) who found that Maghal 1, Zaghloul and Hayany males had great metaxinic effects when used as pollinizers for Zaghloul female. This was due to the high numbers of protein bands and heavy band intensity of proteins of male flowers indicating increased fertility of male pollens, influencing protein pattern and fruit ripening time of Zaghloul cultivar. 

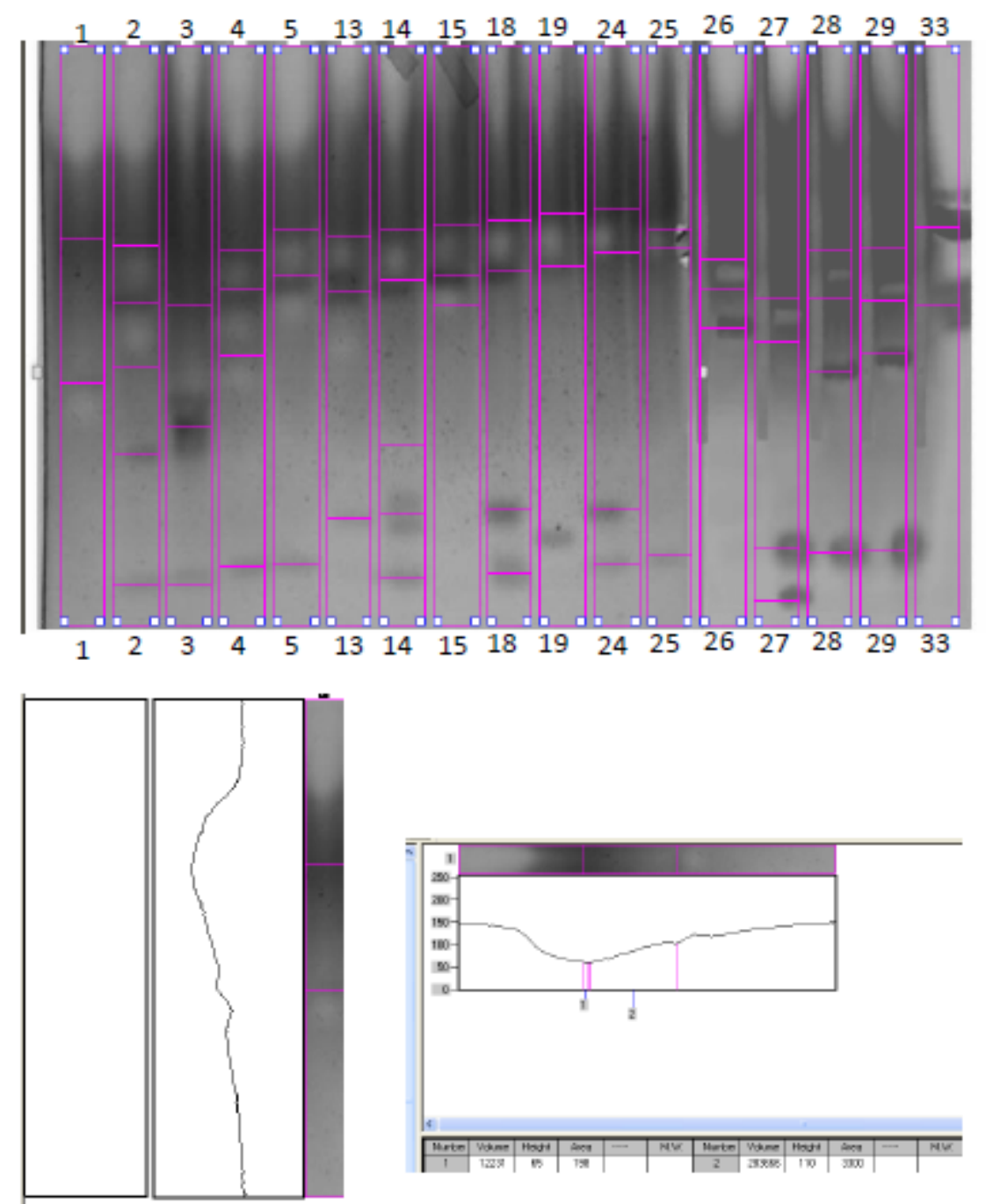

Plate 2. Scanning of SDS-PAGE gel of fruit protein of date palm seeded strains 


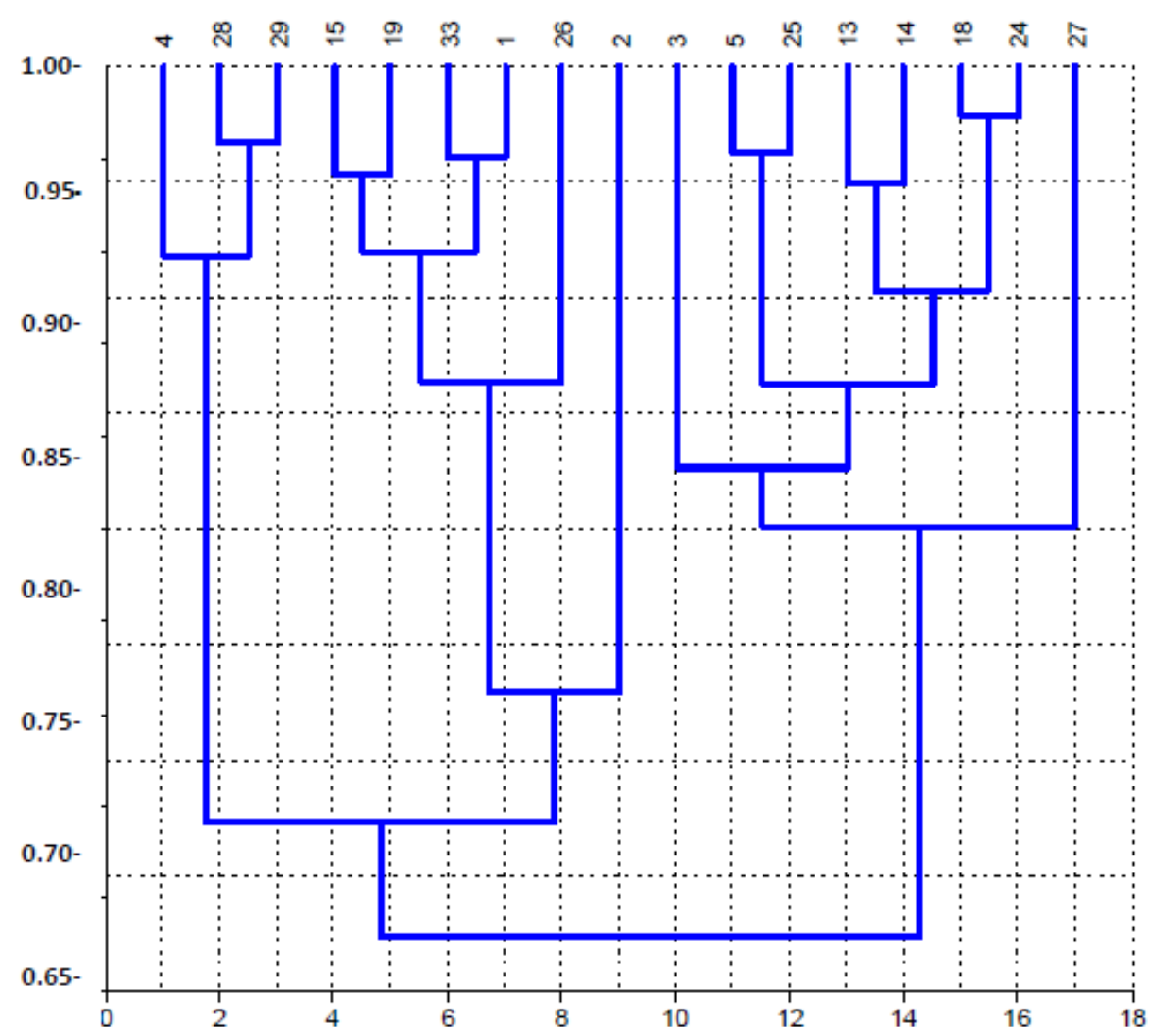

Figure 4. Genetic relationships of date palm seeded strains obtained using electrophoresis pattern of fruit proteins

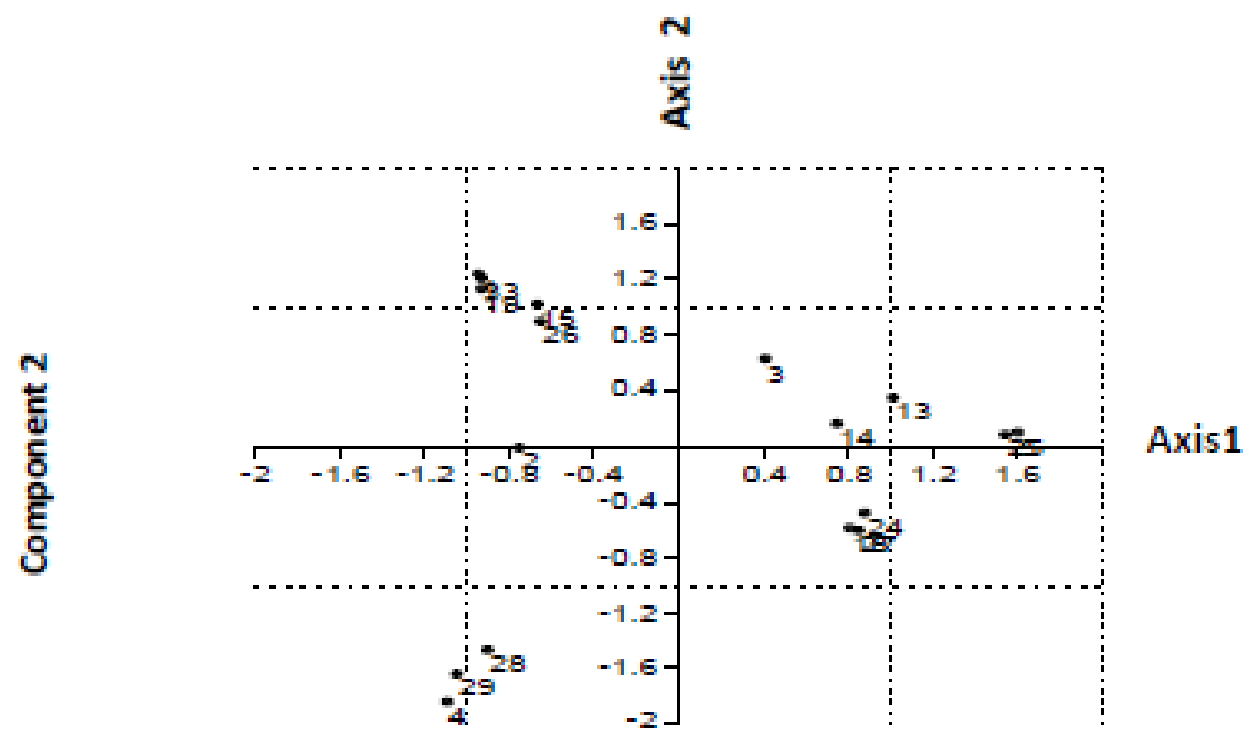

Component 1

Figure 5. First and second principal components ( PC 1 and PC 2 ) from PCA of date palm seeded strains based on fruits protein bands data 


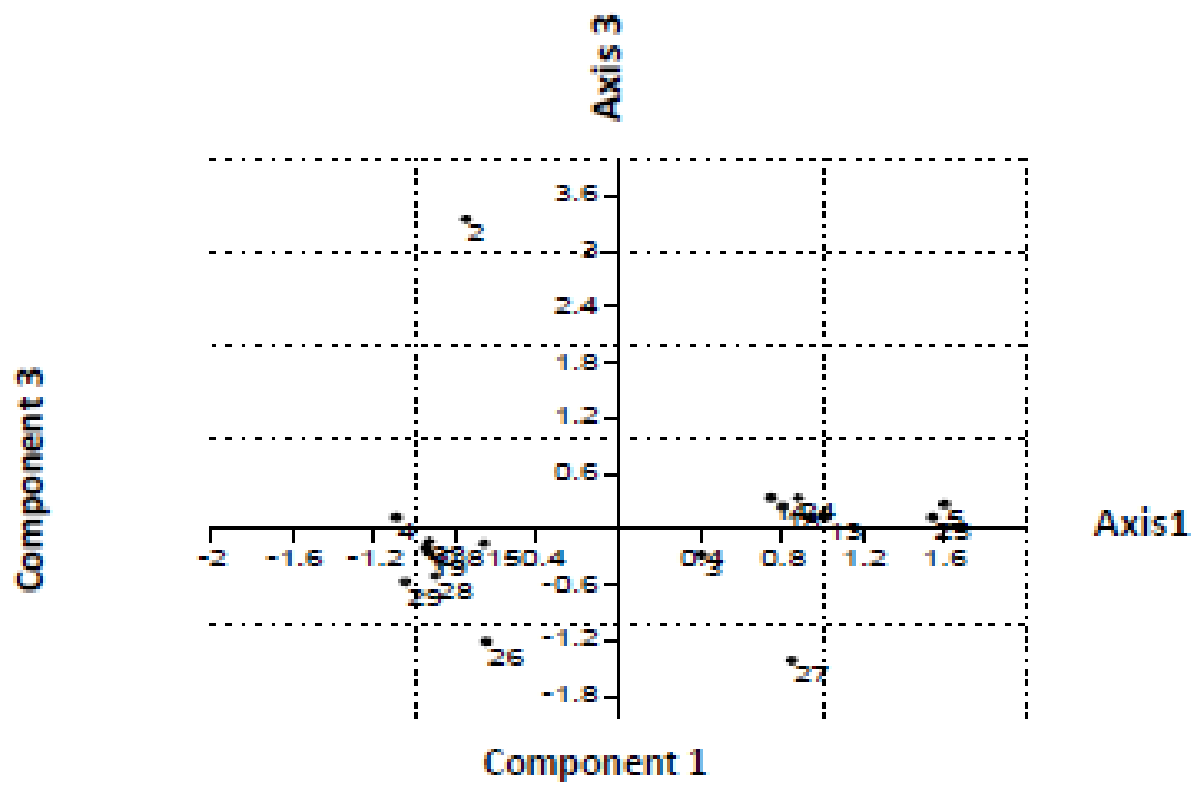

Figure 6. First and third principal components (PC 1 and PC 3) from PCA of date palm Seeded strains based on fruits protein bands data

\section{Conclusion}

Data of the present study clearly indicate that date palm strains had a close genetic relationship. Therefore, it can be concluded that these strains were derived from narrow hybridization origins. On the basis of these findings, further genetic identification to develop a genetic map between the examined strains, mother plants and male pollinizer can be carried out using molecular marker (PCR) techniques.

\section{References}

Abdel-Hamid, N. (2000). Effect of time, rate and patterns of thinning, leaf / bunch ratio and male type on "Zaghloul" date yield and quality. Arab Univ. Agric. Sci., Ain Shams Univ. Cairo, 8(1), 305-317. Retrieved from http://www.cabdirect.org/abstracts/20013083117.html

Abdullah, M., \& Gamal, O. (2010). Investigation on molecular phylogeny of some date palm (Phoenix dactylifera L.) cultivars by protein, RAPD and ISSR markers in Saudi Arabia. Aust. J. Crop Sci, 4(1), 23-28. Retrieved from http://www.cropj.com/gamal_4_1_2010_23_28.pdf

Al-Bakr, A. (1972). Date Palm Tree, Its Past, Present and The News in Its Culture, Industry and Trade Commerce. Al-Ani Press, Baghdad, Iraq.

Al-Esa, A. M. (2006). Ecophysiological comparison between three cultivars of date palm trees in Al-Ahsa and Al-Qatif in Saudi Arabia. Ph. D. Thesis. College of Science, King Saud University.

Al-Qurainy, F. H., Al-Saad, F., \& Fifilan, S. (2006). Comparative study of protein in tissue-culture produced date palm and offshoot origin date palms at different seasons. Saudi J. Biol. Sci., 13(1), 20-31.

Attaha, Ali H. M. (2007). Restoration program of date palm orchards in Basrah Governorate. Proceedings of The First Workshop of Date Palm. College of Agriculture, University of Basrah, Iraq.

Attaha, Ali H. M., \& Taain, D. A. (2011). A comparative study on growth and ripening of fruits in date palm cv. Shewaithy grown in Basrah and Thi-Qar regions. Dirasat, Agricultural Sciences, 38(1, 2), 1-12.

Barrow, S. (1998). A monograph of Phoenix L. (Palmae: Coryphoideae). Kew Bull., 53, 513-575. http://dx.doi.org/10.2307/4110478

Carffin, D. F. (1990). Purification Procedures Electrophoretic Methods. In Methods in Enzymology. In E. D. Murray \& P. J. Dentscher (Eds.), 182, 425-441. 
Elshibli, S., \& Korpelainen, H. (2009). Biodiversity of date palm (Phoenix dactylifera L.) in Sudan: chemical, morphological and DNA polymorphisms of selected cultivars. Plant Genetic Resources: Characterization and Utilization, 7, 194-203. http://dx.doi.org/10.1017/s1479262108197489

El-Sohaimy, S. A., \& Hafez, E. E. (2010). Biochemical and nutritional characterizations of date palm fruits ( Phoenix dactylifera L. ). J. Appl. Sci. Res., 6(8), 1060-1067.

Gomez-Vidal, S., Tena, M., Lopez-Llorca, L. V., \& Salinas, J. (2008). Protein extraction from Phoenix dactylifera L. leaves, a recalcitrant material, for two-dimensional electrophoresis. Electrophoresis., 29, 448-456. http://dx.doi.org/10.1002/elps.200700380

Hadeel, A. S., Jabbar, M. T., \& Chin, X. (2010). Application of remote sensing and GIS in the study of environmental sensitivity to desertification: a case study in Basrah Province, Southern part of Iraq. Applied Geomatics., 2(3), 101-112. http://dx.doi.org/10.1007/s12518-010-0024-y

Howland, J. L. (1996). Current Protocols in Protein Science. In C. Coligan, B. Dunn, H. Ploegh, D. Speicher \& P. Wingfield (Eds.), New York: Jone Wiley and Sons, Inc.

Jaradat, A. A. (2003). Agriculture in Iraq: Resources, potentials, constraints, research needs and priorities. Food, Agriculture and Environment, 1(2), 160-166.

Khoshroo, S. M. R., Khavarinejad, R., Baghizadeh, A., Fahimi. H., \& Mohammadi, Z. N. (2011). Seed storage protein electrophoretic profiles in some Iranian date palm (Phoenix dactylifera L.) cultivars. Afr. $J$. Biotechnol., 10(77), 17793-17804.

Laemmli, U. K. (1970). Cleavage of structural proteins during the assembly of the head of bacteriophage T4. Nature, 227, 680-685. http://dx.doi.org/10.1038/227680a0

MA (Minsitry of Agriculture). (2004). Agriculture Statistical Year Book. The Agriculture Office of Basrah Governorate, Iraq.

Mater, Abdul-Ameer. M. (1991). Date Palm Culture and Its Product. Al-Hikma Press, University of Basrah, Iraq.

Sahi, A. A., \& Al-Anber, L. J. (2005). Isolation and identification of some local date using gel filtration chromatography \& electrophoresis. Basrah. J. Date Palm Res., 4(1-2), 87-110.

Shaheen, M. A., \& El-Meleigi, M. A. (1991). Identification of date palm male cultivars by the electrophoresis pattern of pollen soluble proteins. JKAU. Met. Env. Arid Land Agric. Sci., 2, 97-103.

\section{Copyrights}

Copyright for this article is retained by the author(s), with first publication rights granted to the journal.

This is an open-access article distributed under the terms and conditions of the Creative Commons Attribution license (http://creativecommons.org/licenses/by/3.0/). 